\title{
STRATEGI PENGEMBANGAN WIRAUSAHA MANDIRI MAHASISWA DI MASA PANDEMI COVID-19
} p-ISSN: 2460-5514
e-ISSN: 2502-6518

\author{
Oleh: \\ Ahmad Mustamil Khoiron ${ }^{1}$, Samsudin Anis ${ }^{2}$, Adhi Kusumastuti ${ }^{3}$, Lulut Indrianingrum ${ }^{4}$. \\ Universitas Negeri Semarang \\ amkhoiron@mail.unnes.ac.id
}

\begin{abstract}
Abstrak
Penyebaran virus COVID-19 sangat berdampak diseluruh aspek kehidupan masyarakat, khususnya dibidang ekonomi diseluruh dunia termasuk di Indonesia. Tidak terkecuali pada pelaku usaha mahasiswa yang telah dibina oleh Program Pengembangan Kewirausahaan (PPK) Fakultas Teknik Universitas Negeri Semarang tahap pertama. PPK merupakan salah satu program pengabdian kepada masyarakat yakni dibidang pengembangan usaha mandiri mahasiswa khususnya. PPK bertujuan untuk mengembangkan jiwa dan potensi mahasiswa dalam berwirausaha dengan bersinergi dengan penguasaan teknologi yang dimiliki oleh mahasiswa. Metode pelaksanaan kegiatan PPK adalah secara demonstrasi dan pembinaan tenant. Proses pelaksanaan terdiri atas enam tahapan yakni: (1) rekruitment tenant dan pembentukan kelompok usaha, (2) webinar study banding, (3) webinar sertifikasi produk dan kegalitas usaha, (4) pemberian dana stimulus tenant, (5) pendampingan usaha, (6) monitoring dan evaluasi. Berdasarkan pelaksanaan PPK di Fakultas Teknik Universitas Negeri Semarang diperoleh hasil bahwa terdapat wirausaha mahasiswa yang mampu bertahan dan stabil pada masa pandemi COVID-19 antara lain dibidang kuliner, jasa kecantikan, dan produk busana. Pendampingan kewirausahaan mahasiswa yang dilakakukan memberikan sumbangsi dalam penguatan kegiatan berwirausaha dimasa pandemi COVID-19.
\end{abstract}

Kata Kunci: pengembangan, wirausaha, pandemi COVID-19

\begin{abstract}
The spread of COVID-19 bring a great impact on all aspects of social life, specifically on the economic sector around the world, including Indonesia. There is no exception for student business actors who has been fostered by the Entrepreneurship Development Program (PPK) of the first phase of Engineering Faculty, Universitas Negeri Semarang. PPK is one of the community service programs which is focused on the independent entrepreneurship development for students. The PPK is aimed to develop the students entrepreneurial spirit and ability by synergizing the mastery of technology possessed by students. The implementation method of PPK activities are demonstration and tenant coaching. The implementation process consists of six stages, namely: (1) recruitment of tenants and the business groups formation, (2) comparative study webinars, (3) webinars of product certification and business activities, (4) provision of tenant stimulus funds, (5) business assistance, (6) monitoring and evaluation. Based on the implementation of the PPK at the Faculty of Engineering, Universitas Negeri Semarang, it is found that there are student entrepreneurs who are able to survive and be stable during the COVID-19 pandemic, including in the fields of culinary, beauty services, and fashion products. The student entrepreneurship assistance that is carried out has contributed to strengthening entrepreneurial activities during the COVID-19 pandemic.
\end{abstract}

Keywords: development, entrepreneurship, the COVID-19 pandemic

Penyebaran virus COVID-19 bukan hanya terjadi di Indonesia bahkan di seluruh dunia. Karena penyebarannya yang semakin meluas, menyebabkan perubahan dan berdampak diseluruh sektor kehidupan diantara yaitu kesehatan, pendidikan, sosial 
dan tidak terkecuali pada aspek ekonomi. Dampak virus COVID-19 ini sangat besar pengaruhnya terhadap perekonomian para pelaku usaha baik usaha besar, usaha mikro, kecil dan menengah (UMKM). Seperti yang dikemukakan oleh Abdi (2020) bahwa dampak virus COVID-19 yang terlihat tidak hanya mempengaruhi kesehatan masyarakat, akan tetapi turut mempengaruhi perekonomian negara dimana semakin meluasnya wabah corona ke berbagai belahan dunia menjadi ancaman serius bagi perekonomian global.

Pemerintah Indonesia masih berupaya untuk menangani dan memulihkan perekonomian nasional. Salah satu upaya yakni dikutip dari CNN Indonesia (2020) bahwa Presiden Jokowi merilis aturan skema pemulihan ekonomi nasional dari dampak dan tekanan virus corona. Aturan itu tertuang dalam Peraturan Pemerintah Nomor 23 Tahun 2020 tentang Pelaksanaan Program Pemulihan Ekonomi Nasional dalam Rangka Mendukung Kebijakan Keuangan Negara untuk Penanganan Pandemi Corona Virus Disease 2019 dan atau Menghadapi Ancaman yang Membahayakan Perekonomian Nasional dan atau Stabilitas Sistem Keuangan serta Penyelamatan Ekonomi Nasional.

Pandemi COVID-19 tidak saja berdampak pada perusahaan besar tetapi juga berdampak pada kelangsungan usaha kecil dan menengah dan pekerjanya. Penurunan penjualan dan pendapatan serta terganggunya distribusi bahan baku sebagai imbas COVID-19 menyebabkan pelaku usaha mengurangi kegiatan produksi bahkan menghentikan produksi. Berdasarkan data yang diolah P2E LIPI, dampak penurunan pariwisata terhadap UMKM yang bergerak di usaha makanan dan minuman (mamin) mikro mencapai $27 \%$. Sedangkan, dampak terhadap usaha kecil makanan dan minuman sebesar $1,77 \%$ dan usaha menengah di angka $0,07 \%$. Selain itu, pengaruh virus corona terhadap unit usaha kerajinan dari kayu dan rotan, usaha mikro akan berada di angka $17,03 \%$. Untuk usaha kecil di sektor kerajinan kayu dan rotan $1,77 \%$ dan usaha menengah $0,01 \%$. Sementara itu, konsumsi rumah tangga juga akan terkoreksi antara 0,5\% hingga 0,8\% (Widowati, 2020).

Berdasarkan hasil survei LIPI, pandemi COVID-19 menyebabkan 39,4\% pengusaha menghentikan kegiatan produksi, dan $57,1 \%$ usaha tetap berjalan tetapi produksi menurun. Usaha yang banyak terhenti kegiatan usaha adalah jenis usaha yang banyak melakukan interaksi dengan orang lain, seperti perdagangan ritel sebesar $45,2 \%$ dan jasa kemasyarakatan sebesar 49,8\%. Begitu juga jenis usaha yang membutuhkan modal dan tenaga kerja yang cukup banyak, seperti sektor konstruksi dan bangunan sebanyak $44,2 \%$, dan jasa perusahaan sebesar $50,7 \%$ (Asiati, 2020).

Dampak pandemi tersebut juga dirasakan oleh para mahasiswa tenant yang merupakan wirausaha mandiri yang dibentuk pada pelaksanaan PPK tahun pertama yakni ditahun 2019. Terdapat 20 tenant yang dihasilkan pada saat itu yang terdiri atas tujuh bidang usaha yaitu: (1) jasa arsitek, (2) jasa desain grafis, (3) jasa makeup, (4) jasa wedding organizer, (5) produk busana, (6) produk kerajinan, dan (7) produk kuliner. Hasil survey dan wawancara dengan tenant menyatakan bahwa banyak diantara usaha tenant yang berhenti ditengah perjalanan dan tidak mampu melanjutkan usahanya karena menurunya kuantitas permintaan konsumen akan jasa dan produk karena adanya pembatasan sosial di masa pandemi COVID19 sehingga banyak terjadi kerugian yang dirasakan oleh para tenant. Permasalahan tersebut tidak dapat dibiarkan begitu saja. Oleh karena itu, tim pengabdian harus merekrut dan memfiltrasi kembali tenant yang akan memperoleh pendampingan pada pelaksanaan PPK di tahun kedua yakni tahun 2020.

Menurut Frinces (2010) wirausaha adalah orang yang kreatif, dinamis dan inovatif, dan dia mau mengambil berbagai jenis risiko dan berani menghadapi semua tantangan yang tidak dapat diprediksi dan diramalkan sebelumnya, lewat kreativitasnya dan kekuatan kemauan (the will power) untuk mencapai sukses. Lebih lanjut dikemukakan bahwa semangat keberanian yang dimiliki oleh wirausaha membantu untuk mengembangkan dan mempenetrasi berbagai bidang bisnis baru agar supaya menjadi kompetitif sehingga mereka dapat menawarkan lebih banyak pilihan-pilihan kepada masyarakat. Sedangkan menurut Lestari \& Djamilah (2020) wirausaha adalah seorang yang berani berusaha secara mandiri dengan mengerahkan segala sumber daya dan upaya meliputi kepandaian mengenali produk baru, menentukan cara produksi baru, menyusun operasi untuk pengadaan produk baru, memasarkannya, serta mengatur permodalan operasinya untuk 
menghasilkan sesuatu yang bernilai lebih tinggi

Berdasarkan pengalaman dan hasil yang diperoleh pada pelaksanaan PPK tahun pertama ditemukan bahwa masih banyak terdapat kendala yang dialami oleh para tenant dalam menjalankan usahanya diantaranya yaitu masih kurangnya semangat dan motivasi yang dimiliki oleh para tenant untuk bersaing dengan usaha lainnya. Terlebih lagi karena kondisi yang memaksa para pelaku usaha khususnya para tenant untuk lebih kreatif dan inovatif dalam mengelola usaha yang dirintis. Menurut Faisal \& Anthoni (2020) salah satu motivasi para Mahasiswa mau berwirausaha tentunya menginginkan adanya perbaikan kondisi ekonomi mereka. Selain itu, salah satu keberhasilan berwirausaha tidak lepas hanya pada pendidikan baik formal maupun informal, motivasi, minat yang mempengaruhi.

Selain itu berdasarkan hasil PPK ditahun pertama, masih diperlukannya pendampingan untuk membentuk wirausaha mandiri diantaranya yaitu: (1) diperlukannya study banding untuk memperoleh informasi dan pengalaman terkait bidang usaha yang dijalankan dalam rangka meningkatkan kualitas produk dan kreatifitas dalam mengembangkan produk usaha, (2) diperlukannya kerjasama yang lebih intensif dengan mitra usaha baik dalam bentuk kegiatan bersama misalnya pameran produk, konsultasi bisnis dan sebagainya, dan (3) diperlukannya ilmu dan pengetahuan tentang legalitas produk dan tata cara memperoleh sertifikasi produk untuk para usaha tenant.

Berdasarkan hal tersebut, untuk mengatasi permasalahan yang telah dikemukakan di atas, maka perlu dilakukan upaya pendampingan pengembangan wirausaha mandiri untuk para tenant pada pelaksanaa PPK tahun kedua di Fakultas Teknik melalui rekruitmen wirausaha mandiri, study banding dengan para pelaku usaha, pemberian materi dan pembimbingan terkait legalitas usaha dan sertifikasi produk.

\section{METODE}

Metode pelaksanaan kegiatan dilakukan secara demonstrasi dan pembinaan. Sementara, data dianalisis menggunakan teknik analisis data deskriptif. Adapun tahapan kegiatan PPK yang dilakukan berdasar pada identifikasi masalah yang ditemukan antara lain:

\section{Tahapan Rekrutmen Tenant dan Pembentukan Kelompok Usaha}

Rekruitmen dan filtrasi usaha tenant dilakukan untuk menjaring usaha tenant baru dan lama yang mampu untuk bertahan di masa pandemi COVID-19 dan siap bersaing di dunia usaha.

\section{Webinar Study Banding}

Adapun materi pada kegiatan webinar 1 terkait study banding antara lain:

a. Proses dalam mendirikan usaha (followup dari ide)

b. Kemudahan dan kesulitan yang dihadapi

c. Integritas dan mentalitas pelaku usaha

d. Bagaimana produk menjadi solusi permasalahan di era pandemi COVID19

e. Perencanaan usaha/bussines plan

f. Bagaimana cara mendapatkan investor/mendapatkan modal usaha

g. Managemen usaha

h. Marketing (sales activity, market share)

i. Promosi

j. Pemanfataan Sistem Teknologi (pengelolaan dan pemantauan usaha secara real time).

3. Webinar Sertifikasi Produk dan Legalitas Usaha

Kegiatan webinar sertifikasi produk dan legalitas usaha merupakan kegiatan lanjutan dari webinar study banding yang dilakukan pada tahap sebelumnya. Materi dalam webinar ini terdiri atas 2 pokok bahasan yaitu materi legalitas usaha dan legalitas produk. Pada pelatihan ditahun kedua terdapat pelatihan legalitas usaha dan produk melalui legal clinic. Dimana pada legal clinic tenant dapat merealisasikan penyusunan draft legalitas usaha dan produk. Pelatihan dilakukan dengan melibatkan Pusat Desiminasi Teknologi dan Kekayaan Intelektual Unnes. Sehingga luaran dari pelatihan yang dilakukan adalah kesiapan produk dan kepercayaan diri tenant dalam berwirausaha

4. Pemberian Dana Stimulus Alat Bantu Proses Produksi Produk/Jasa Usaha

Pemberian dana stimulus untuk alat bantu proses produksi kepada tenant bertujuan untuk memberikan dana awal usaha dan motivasi untuk menjalankan usaha dengan baik. Besaran dana stimulus yang 
diberikan tergantung kepada analisis kebutuhan dan penetapan yang dilakukan oleh tim pelaksana pengabdian. Tenant yang berjumlah 17 akan diberikan bantuan stimulus dalam bentuk teknologi, peralatan produksi maupun pemasaran produk/jasa sesuai dengan jenis usahanya. Pemberian bantuan dilakukan setelah tenant telah mendapatkan persiapan dalam bentuk pelatihan, pendampingan usaha, studi banding, dan evaluasi usaha. Sehingga bantuan tersebut lebih dapat dimaksimalkan karena tenant sudah mendapat dasar pengetahuan dan keterampilan untuk menjalankan wirausaha.

\section{Pendampingan Usaha}

Pada pelaksanaan PPK ditahun kedua, tenant tetap diberikan pendampingan usaha dan bimbingan melalui business assistance Pendampingan usaha dilakukan dengan melibatkan berbagai lembaga pengembang kewirausahaan khususnya yang berada di Fakultas Teknik dengan mitra lembaga kewirausahaan dan industri seperti UNSEC dan UMKM Center Jawa Tengah.

\section{Evaluasi}

Evaluasi dilakukan sekali setiap bulan dalam bentuk laporan kemajuan sementara terhadap usaha yang dijalankan, sebagai upaya untuk meningkatkan kemandirian dalam berwirausaha. Proses evaluasi dilakukan juga sebagai bentuk diskusi dan penyelesaian masalah wirausaha yang jalankan oleh tenant, dengan harapan perkembangan wirausaha tenant menuju mandiri lebih efektif.

\section{HASIL DAN PEMBAHASAN}

\section{Pelaksanaan}

Realisasi pelaksanan PPK Fakultas Teknik Universitas Negeri Semarang dilakukan sejak tahun pertama ditahun 2019. Namun untuk tahap kedua ini di tahun 2020, tahapan kegiatannya dilaksanakan secara daring dan tatap muka sesuai dengan protokol kesehatan yang diakibatkan oleh adanya penyebaran virus COVID-19. Adapun hasil tahapan yang dilakukan adalah sebagai berikut:

\section{a. Rekrutmen Peserta PPK (Tenant)}

Penentuan tenant ditahun kedua menyesuaikan dengan perkembangan usaha mahasiswa pada saat pandemi COVID-19, dengan memfiltrasi usaha yang memiliki potensi pada saat pandemi dan keberlanjutan usaha dimasa pandemi COVID-19. Berdasarkan hasil rekruitmen, diperoleh 17 usaha tenant yang akan memperoleh pendampingan untuk pelaksanaan PPK di Fakultas Teknik Universitas Negeri Semarang antara lain yaitu: (1) Master Barbershop, (2) Vanesa Make-up, (3) Lydia Beauty, (4) Hayare.ID, (5) Vanessha Hijab, (6) Ayre Desain, (7) Rach Style, (8) Lyra Collection, (9) Waris Modiste, (10) Cengkir Unique Craft, (11) Art dan Trashlane Streetwear, (12) Ubi Lumer, (13) Salad'Co, (14) Sambal DW, (15) Kersso (kerupuk Siomay), (16) Pentol Bledos, dan (17) SuNdukan.

\section{b. Webinar Study Banding}

Study banding tenant usaha mahasiswa FT dengan tema "Preparing Our Business to Survive During the New Normal", peserta tidak hanya diikuti oleh tenant FT UNNES akan tetapi webinar dibuka untuk seluruh mahasiswa FT yang berminat dan ingin belajar dalam berwirausaha.



Gambar 1. Flayer webinar study banding tenant FT UNNES 
Adapun isi materi webinar tersebut meliputi:

1) Proses dalam mendirikan usaha (followup dari ide)

2) Kemudahan dan kesulitan yang dihadapi

3) Integritas dan mentalitas pelaku usaha

4) Bagaimana produk menjadi solusi permasalahan di era pandemi COVID-19

5) Perencanaan usaha/bussines plan

6) Bagaimana cara mendapatkan investor/mendapatkan modal usaha

7) Managemen usaha

8) Marketing (sales activity, market share)

9) Promosi

10) Pemanfataan Sistem Teknologi (pengelolaan dan pemantauan usaha secara real time)

Pemateri pertama adalah Asdar Habib Owner Brand Desainer "ASDAR HABIB" dan Owner A5hab Wear; dan Gia Panji Puetera CEO ICVC (Entertaiment Production) dan CEO Mrs. Chic Smoked Chicken sebagai pemateri kedua.

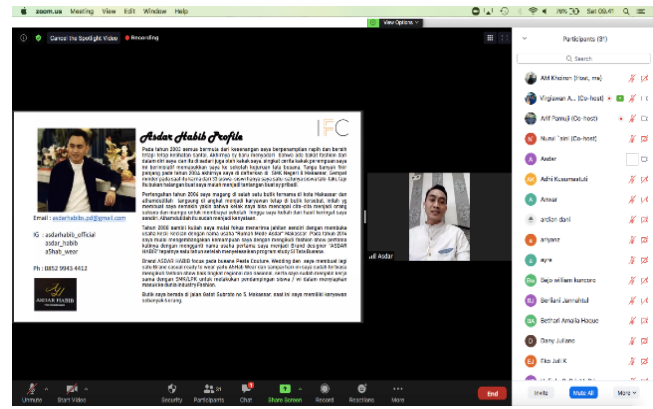

Gambar 2. Pemaparan materi pertama oleh Asdar Habib

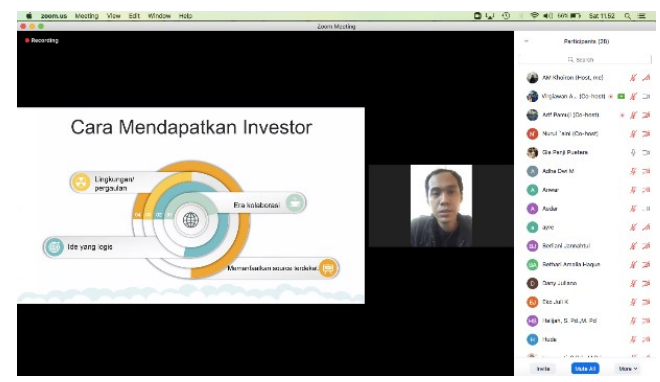

Gambar 3. Pemaparan materi pertama oleh Gia Panji Puetera CEO ICVC c. Webinar Sertifikasi produk dan Legalitas Usaha

Webinar sertifikasi produk dan legalitas usaha tenant Program Pengembangan Kewirausahaan Fakultas Teknik UNNES dengan tema;" melalui sertifikasi produk dan Legalitas Usaha mewujudkan Wirausaha Mandiri dan berdaya saing dalam menghadapi New Normal".



Gambar 4. Flayer webinar sertifikasi produk dan legalitas usaha

Gambar 4 merupakan bentuk Flayer webinar yang disebar luaskan untuk khalayak umum khususnya bagi tenant Program Pengembangan Kewirausahaan Fakultas Teknik UNNES agar dapat mengikuti dan berpartisipasi dalam kegiatan webinar tersebut yang terdiri atas dua pemateri yang membahas tentang sertifikasi produk dan legalitas usaha.

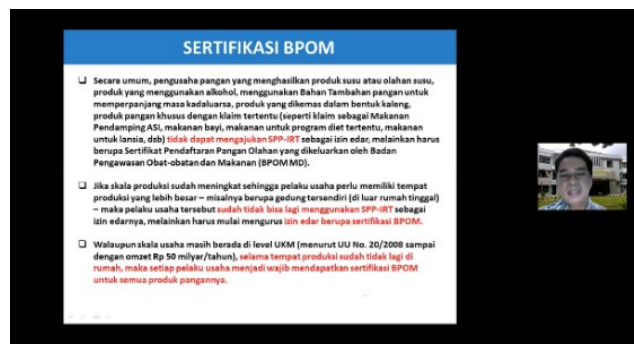

Gambar 5. Pemaparan materi webinar terkait sertifikasi produk oleh bapak Drs. Sunyoto, M.Si 
Materi sertifikasi produk yang dibawakan oleh bapak Drs. Sunyoto, M.Si berupa pengetahuan dan pemahaman macam-macam sertifikasi produk tergantung dari skala usaha masingmasing yang diantaranya adalah PIRT, SNI, HAKI (merk dagang, desain industri, paten sederhana, paten biasa), Halal dan BPOM.

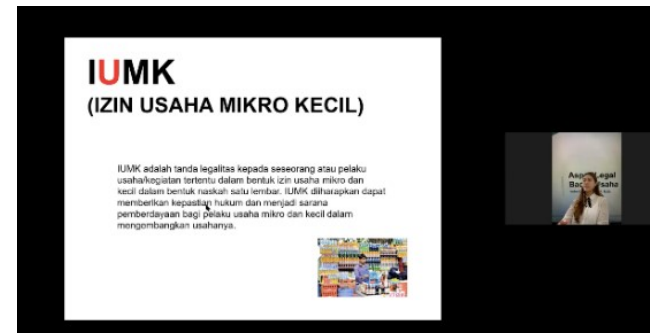

Gambar 6. Pemaparan materi legalitas usaha oleh Ibu Indira Gustiar, S.S., S.H., M.Kn

Selanjutnya, materi kedua yang disampaikan oleh Ibu Indira Gustiar, S.S., S.H., M.Kn membawakan materi legalitas usaha yang berupa tujuan dan manfaat serta keunggulan dan manfaat bagi usaha yang memiliki legalitas usaha. Selain itu, dalam materi ini juga dipaparkan tentang hal-hal yang perlu dipersiapkan bagi setiap usaha diantaranya yaitu TDP (Tanda Daftar Perusahaan), SIUP (Surat Izin Usaha Perdagangan dan NIB (Nomor Induk Berusaha), SITU (Surat Izin Tempat Usaha), IUMK (Izin Usaha Mikro Kecil). Selain itu, peserta juga diberikan pengetahuan tentang macam-macam skala usaha yakni CV (Commanditaire Vennootschap) (Persekutuan Komanditer) dan PT (Perseroan Terbatas).

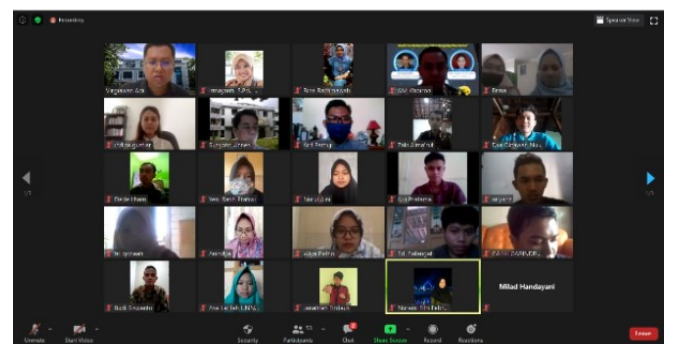

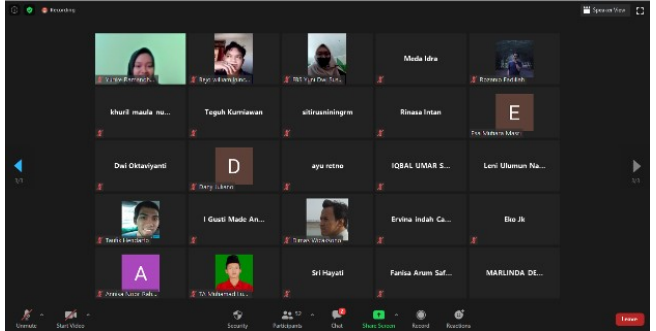

Gambar 7. Peserta webinar sertifikasi produk dan legalitas usaha

Gambar 7 merupakan dokumentasi peserta yang mengikuti webinar sertifikasi produk dan legalitas usaha yang dilaksanakan pada hari Kamis, 13 Agustus 2020 yang berjumlah sebanyak 53 orang.

\section{d. Pemberian Dana Stimulus Tenant}

Dana Stimulus diberikan kepada 17 tenant sebesar RP. 50.000.000, untuk mendukung kegiatan berwirausaha mahasiswa $\mathrm{Hal}$ ini sangat dibutuhkan tenant karena dampak dari pandemi COVID-19 membuat usaha tenant harus mendapatkan dana segar untuk mempertahankan usaha mereka dan terdapat tenant yang berganti usaha dengan membaca peluang pada saat pandemi COVID-19. Berikut dokumentasi kegiatan pemberian dana stimulus tenant yang diberikan langsung oleh ketua tim pelaksana kegiatan PPK yang ditunjukkan pada gambar 8 .






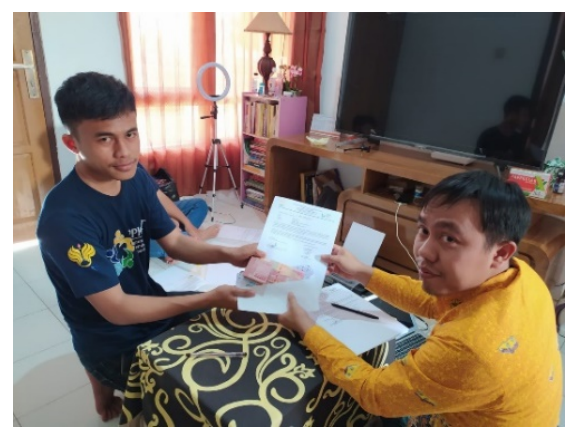

Gambar 8. Pemberian dana stimulus untuk tenant FT UNNES

\section{e. Pendampingan Wirausaha}

Pendampingan wirausaha yang dilakukan pada PPK yaitu melalui business assistance untuk merealisasikan luaran pelatihan dan dalam menjalankan usaha sesuai dengan jenis dan bidang usahanya. Selama proses pendampingan yang telah dilakukan, tenant memperoleh arahan dan bimbingan tentang kiat bisnis mencapai target yang telah ditentukan serta pemecahan masalah-masalah yang dihadapi dalam merencanakan ataupun menjalankan usahanya.

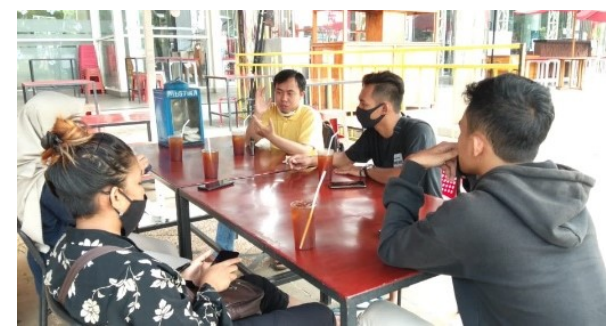

Gambar 9. Konsultasi terkait usaha yang dijalankan oleh tenant

Gambar 9 merupakan dokumentasi salah satu kegiatan pendampingan usaha tenant dimana ketua tim pelaksana dan anggota langsung memberikan arahan dan bimbingan terkait usaha tenant. Pelaksanaan pendampingan dimulai dari proses produksi, packaging, pemasaran hingga teknik manajemen usaha secara keseluruhan. Pendampingan dan bimbingan dilaksanakan melalui diskusi kelompok kecil mahasiswa tenant dengan pembimbing.

\section{f. Monitoring dan Evaluasi}

Kegiatan monitoring dan evaluasi merupakan upaya untuk melihat perkembangan dan pengendalian secara internal agar pelaksanaan PPK dapat berjalan dengan baik. Berikut dokumentasi kegiatan monitoring dan evaluasi usaha tenant yang dilaksanakan secara daring yang ditunjukkan pada gambar 10 .

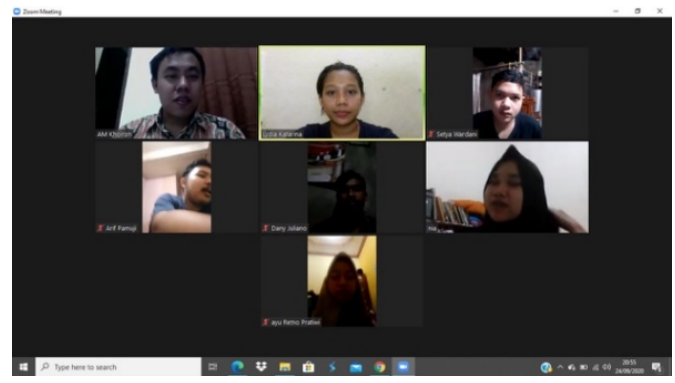

Gambar 10. Monitoring dan evaluasi usaha secara daring bersama para tenant

Monitoring dilakukan oleh tim pelaksana PPK satu kali dalam sebulan baik dalam bentuk laporan kemajuan sementara terhadap usaha yang dijalankan, sebagai upaya untuk meningkatkan kemandirian dalam berwirausaha. Proses evaluasi dilakukan juga sebagai bentuk diskusi dan penyelesaian masalah wirausaha yang dilakukan oleh tenant, dengan harapan perkembangan wirausaha tenant menuju mandiri lebih efektif.

\section{Dampak Ekonomi dan Sosial}

Selanjutnya setelah diadakan beberapa tahapan pelaksanaan PPK, terdapat dampak ekonomi dan sosial dari kegiatan tersebut. Berdasarkan data yang diperoleh membuktikan bahwa terdapat peningkatan pendapatan tenant secara signifikan dari kegiatan PPK yang dinilai dari 3 indikator yaitu dampak terhadap pendapatan, aktivitas ekonomi dan pengeluaran. Hal tersebut terjadi karena adanya dana stimulus tahap ke-2 yang diberikan kepada usaha tenant untuk lebih meningkatkan promosi dan produktivitas usahanya.

Kemudian dari segi aktivitas ekonomi, mengalami penurunan yang diakibatkan oleh keterbatasan penjualan akibat pandemi COVID-19 yang hampir terjadi pada semua tenant. Kemudian untuk dampak terhadap pengeluaran, tenant tidak terlalu mengalami kerugian dalam artian jumlah pendapatannya lebih besar dari pada pengeluaran walaupun promosi jasanya pada umumnya melalui onlineshop. Persentase peningkatan usaha 
mitra yang merupakan dampak ekonomi dapat dilihat pada grafik berikut:

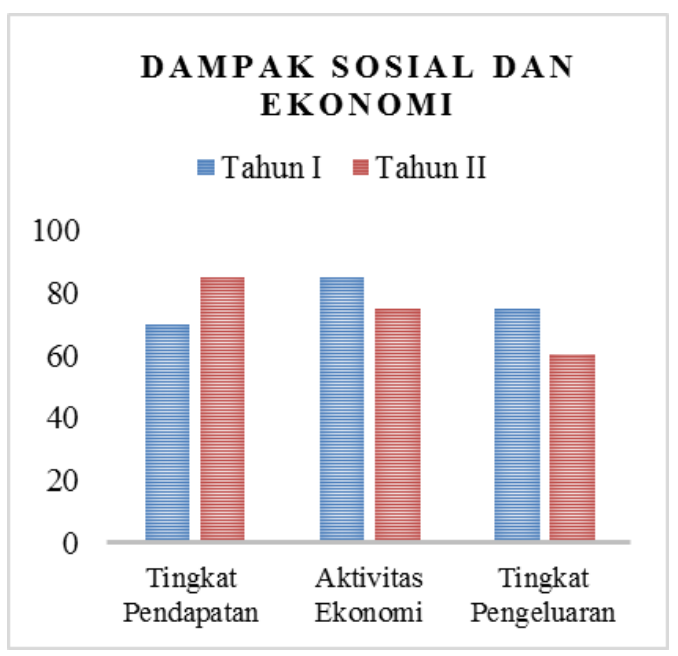

Gambar 11. Grafik dampak sosial dan ekonomi mitra

Pada gambar 11 di atas menunjukkan bahwa tingkat pendapatan tenant naik sebanyak $15 \%$ ditahun 1 pendapatan usaha sebesar $70 \%$ dan ditahun ke-2 naik menjadi $85 \%$. Usaha tenant mengalami peningkatan karena pelayan jasa dan penjualan tetap dilakukan walaupun dilakukan secara online. Kenaikan yang tidak terlalu signifikan tersebut disebabkan adanya keterbatan penjualan dan pelayanan jasa dimasa pandemi COVID-19. Sedangkan untuk aktivitas ekonomi mengalami penurunan sebanyak $10 \%$ yang awalnya pada tahun 1 , promosi, penjualan dan pelayanan usaha tenant sangat aktif. Namun di tahun ke-2 mengalami penurunan menjadi $75 \%$ karena kurangnya konsumen dimasa pandemi COVID-19.

Selanjutnya untuk tingkat pendapatan tenant menjadi menurun sebanyak $15 \%$ yang ditahun pertama sebesar $75 \%$ sedangkan ditahun kedua menjadi $60 \%$. Hal tersebut disebabkan oleh kurangnya bahan-bahan produksi yang disiapkan oleh tenant. Bahanbahan produksi disiapkan jika ada pelanggan/konsumen yang memerlukan jasa maupun produk tertentu.

Berikut merupakan beberapa kegiatan produksi dan penjualan yang dirasakan oleh tenant sebagai dampak ekonomi dalam peningkatan usahanya yang tetap bertahan dan berjalan dimasa pandemi COVID-19 yang dapat dilihat pada gambar 12 di bawah ini.

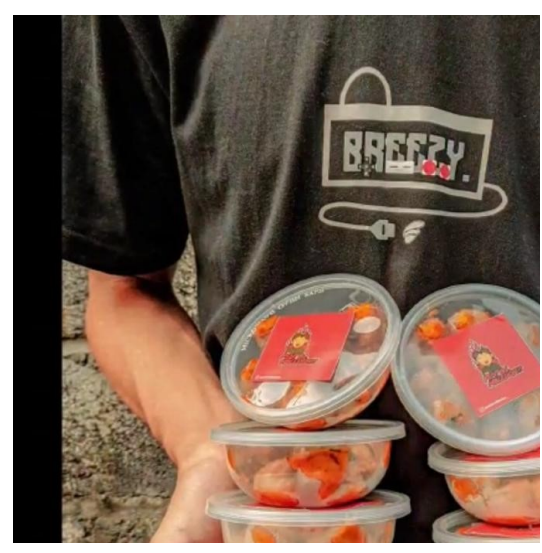

Gambar 12. Produk Pentol Bledos
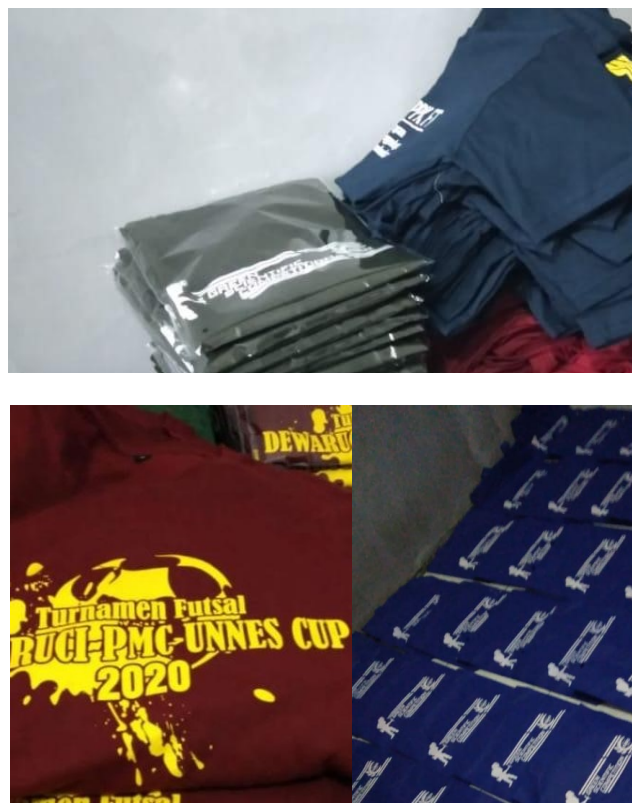

Gambar 13. Jasa kerajinan sablon

3.

ontribusi Mitra terhadap Pelaksanaan

Partisipasi mitra sangat berperan penting dalam realisasi pelaksanaan PPK ini karena tingkat kontribusi mitra yang menjadi tolak ukur keberhasilan. Berdasarkan hasil survei pelaksanaan kegiatan, peran mitra sangat berkontribusi terhadap pencapaian hasil pelaksanaan. Hal tersebut dilihat dari keaktifan mitra dalam pelaksanaan webinar study banding dan webinar sertifikasi produk dan legalitas usaha. Selain itu, kontribusi dari mitra juga dinilai dari hasil pendampingan yang telah dilakukan yang berdasarkan jenis 
usahanya. Hail tersebut dapat dilihat pada tabel 1 di bawah ini:

Tabel 1. Pendampingan Teknis kepada Tenant

\begin{tabular}{|c|c|c|c|}
\hline No. & Jenis Usaha & Pendampingan & Hasil yang Dicapai \\
\hline 1. & $\begin{array}{l}\text { Jasa Hair Style: } \\
\text { Master Babershop }\end{array}$ & $\begin{array}{l}\text { Teknik Pemangkas rambut dan } \\
\text { kreatifitas dalam promosi untuk } \\
\text { mencari costumer, teknik digital } \\
\text { marketing dan manajemen } \\
\text { organisasi }\end{array}$ & $\begin{array}{l}\text { Tenant memiliki kompetensi yang } \\
\text { memadai dalam memotong rambut } \\
\text { dan Jaringan pemasaran jasa potong } \\
\text { rambut semakin luas serta perbaikan } \\
\text { manajemen usaha. }\end{array}$ \\
\hline 2. & Jasa Makeup & $\begin{array}{l}\text { Teknik makeup dan style } \\
\text { makeup sesuai trend mode } \\
\text { masa kini untuk peningkatan } \\
\text { kualitas jasa }\end{array}$ & $\begin{array}{l}\text { Peningkatan Kompetensi tenant } \\
\text { dalam style semua tenant jasa } \\
\text { makeup, dan jumlah costumer yang } \\
\text { semakin meningkat. }\end{array}$ \\
\hline 3. & Produk Pakaian & $\begin{array}{l}\text { Teknik pengembangan produk } \\
\text { dan kualitas produk busana } \\
\text { serta teknik digital marketing }\end{array}$ & $\begin{array}{l}\text { Kompetensi dalam menciptakan } \\
\text { model-model busana yang trend } \\
\text { masa kini, produksi busana yang } \\
\text { semakin meningkat dan ditunjang } \\
\text { oleh kualitas busana yang semakin } \\
\text { baik sehingga meningkatkan } \\
\text { kepercayaan pelanggan dan } \\
\text { kuantitas costumer. }\end{array}$ \\
\hline 4. & Produk kerajinan & $\begin{array}{l}\text { Teknik variasi produk/jasa, } \\
\text { packaging produk dan teknik } \\
\text { marketing }\end{array}$ & $\begin{array}{l}\text { Tenant lebih terampil dalam } \\
\text { membuat variasi kerajinan, } \\
\text { perbaikan manajemen usaha dan } \\
\text { usaha yang mulai dikenal oleh } \\
\text { masyarakat karena promosi usaha } \\
\text { yang lebih baik. }\end{array}$ \\
\hline 5. & Produk Kuliner & $\begin{array}{l}\text { Teknik packaging produk, digital } \\
\text { marketing, dan manajemen } \\
\text { produksi. }\end{array}$ & $\begin{array}{l}\text { Packaging produk dengan tampilan } \\
\text { yang lebih menarik, perbaikan } \\
\text { manajemen produksi sehingga } \\
\text { mempercepat proses produksi dan } \\
\text { menambah kuantitas prduksi. }\end{array}$ \\
\hline
\end{tabular}

4. aktor Pendukung dan Faktor Penghambat

Pelaksanaan kegiatan PPK di Fakultas Teknik Universitas Negeri Semarang dinilai berhasil karena adanya dukungan dari semua pihak terkait khususnya dari tenant. Hal tersebut dilihat dari keaktifan dari tenant dalam mengikuti tahapan kegiatan mulai dari webinar, pendampingan dan pelaksanaan usaha tenant.

Selain faktor pendukung, pelaksanaan kegiatan PPK juga memiliki beberapa hambatan dalam pelaksanaannya. Adapun faktor penghambat tersebut yaitu:

a.

ampir semua kegiatan pada tahapan pelaksaaan PPK terhambat karena adanya pandemi virus COVID-19. Terdapat beberapa tahapan pelaksanaan yang harus dilakukan secara daring diantaranya proses pendampingan dan evaluasi usaha. Hal ini dilakukan sebagai upaya untuk menghambat Fenyebaran virus COVID-19

b.

alah satu tahapan pelaksanaan PPK menjadi tidak terlaksana sesuai rencana yaitu magang ke mitra pelaku usaha karena terdapat beberapa mitra yang menolak untuk menerima mahasiswa magang selama masa pandemic COVID19.

Adapun analisis situasi yang menghambat bidang usaha dari 17 tenant mahasiswa antara lain:

a.

danya keterbatasan costumer baik di dalam dan luar kampuls karena diberlakukannya belajar dan bekerja dari rumah sehingga lingkungan kampus dan sekitarnya menjadi sepi. Hal tersebut mengakibatkan penurunan jumlah produksi dan pendapatan bagi usaha tenant. 
b.

anajemen usaha yang masih belum terstruktur dengan baik

c.

ualitas pengemasan produk masih rendah sehingga diperlukan pelatihan bagi para tenant untuk membuat dan menghasilkan kemasan yang kreatif dan inovatif

d.

urangnya manajemen produksi tang tertata dan terstruktur dengan baik

e.

ariasi produk yang masih terbatas sehingga belum sepenuhnya mampu menarik konsumen

erubahan selera konsumen yang terjadi sehingga harus diikuti perkembangannya agar usaha tetap banyak diminati konsumen.

\section{SIMPULAN DAN SARAN}

\section{Simpulan}

Berdasarakan hasil pelaksanaan PPK di Universitas Negeri Semarang, maka dapat disimpulkan bahwa program telah berhasil mencapai seluruh luaran yang merupakan rencana pelaksanaan tahun kedua dari tiga tahun rencana pengembangan kewirausahaan mahasiswa. Hal tersebut dibuktikan dimana seluruh tahapan pelaksanaan PPK telah berjalan dengan lancar walaupun beberapa tahapan dilakukan secara daring. Upaya tersebut dilakukan sebagai upaya untuk menghambat penyebaran COVID 19.

Selanjutnya, berdasarkan hasil survey dan wawancara kepada 17 tenant, diperoleh data bahwa usaha tenant mampu bertahan dan bersaing dalam masa Pandemi COVID-19 dengan menerapkan ilmu dan pengalaman yang telah di bagikan oleh pelaku usaha pada kegiatan webinar study banding. Dampak dari Pandemi COVID-19 juga berakibat pada aktivitas ekonomi mengalami penurunan sebanyak $10 \%$ yang awalnya pada tahun 1 , promosi, penjualan dan pelayanan usaha tenant sangat aktif, namun di tahun ke-2 mengalami penurunan menjadi $75 \%$. Tingkat pendapatan tenant juga menjadi menurun sebanyak $15 \%$ yang ditahun 1 sebesar $75 \%$ sedangkan ditahun kedua menjadi $60 \%$. Hal tersebut disebabkan oleh kurangnya konsumen dimasa Pandemi COVID-19.

\section{Saran}

Selanjutnya berdasarkan plaksanaan dan hasil serta capaian luaran dapat dikemukakan beberapa saran terkait program PPK yaitu diperlukannya evaluksisi secara berkelanjutan untuk memperoleh informasi terkait peningkatan dan penurunan usaha yang dijalankan dalam rangka meningkatkan kualitas produk dan kreatifitas dalam mengembangkan produk usahk ditahun ketiga. Selain itu, juga diperlukan pelatihan dan pendampingan dalam pembuatan kemasan (packaging) yang kveatif dan inovatif untuk membantu peningkatan promosi dan pemasaran produk usaha tenant.

\section{DAFTAR PUSTAKA}

$\mathrm{P}$

Abdi, M. N. (2020). Krisis Ekonomi Global dari Dampak Penyebaran Virus Corona (Covid-19). AkMen Jurnal IImiah, 17(1), 90-98

Asiati, Devi. 2020. Strategi Bertahan Hidup Bagi Pelaku Usaha dan Pekerja di Tengah Pandemi https://kependudukan.lipi.go.id/id/ berita/53-mencatatCovid19/975-strategibertaha-hidup-bagi-pelaku-usaha-danpekerja-di-tengah-pandemi-Covid-19. (diunduh 18 Maret 2021)

CNN Indonesia. 2020. Jokowi Rilis Aturan Pemulihan Ekonomi Akibat Corona. https://www.cnnindonesia.com/ekonomi/2 0200512133959-532-502506/jokowi-rilisaturan-pemulihan-ekonomi-akibat-corona. (diunduh 18 Agustus 2020)

Faisal, R., \& Anthoni, L. (2020). Determinan Keberhasilan Wirausaha Mahasiswa di Kota Tangerang Selatan. Jurnal Pemasaran Kompetitif, 4(1), 115-132.

Frinces, Z. H. (2010). Pentingnya profesi wirausaha di Indonesia. Jurnal ekonomi dan pendidikan, $7(1)$

Lestari, N. A. A. U., \& Djamilah, S. (2020). Solusi Peningkatan Minat Wirausaha Dan Pengurangan Hambatan Minat Wirausaha Mahasiswa. PRAGMATIS, 1(1), 1-6.

Widowati, Hari. 2020. Efek Domino Virus Corona ke Industri Penunjang Pariwisata", https://katadata.co.id/hariwidowati/berita/5 e9a470e04ad6/efek-domino-virus-coronake-industri-penunjang-pariwisata. (diunduh, 18 Maret 2021) 